\title{
Genetic variability of dairy cattle breeds in Lithuania
}

Romualdas Lapickis,

Loreta Griciuvienė,

Asta Aleksandravičienė,

Indrè Lipatova,

Algimantas Paulauskas ${ }^{*}$

Vytautas Magnus University,

K. Donelaičio g. 58,

Kaunas 44248, Lithuania
Large numbers of different scientific studies are conducted to preserve the breeds and improve the existing ones by introducing the variability of the plate genes, which best shows the phenotypic characteristics that can improve the health of dairy cattle and the quality of their production. The main purpose of this study was to perform an analysis of genetic variability of Lithuanian cattle breeds. Three subpopulation groups were studied: Lithuanian Black and White (95 individuals), Lithuanian Red (49), and Lithuanian White and Red (48). Bovine genetic material was genotyped using a total of 11 fluorescent microsatellite primers to estimate genetic variability. All loci presented a high degree of polymorphism and a total of 292 different alleles $(\mathrm{Na})$ were detected. Thirty-two private alleles were detected in all evaluated subpopulations. After completing pairwise population assignment, which is based on the distribution of allelic frequencies, three populations showed the tendency to group into three separate clusters. However, the performed Principal Coordinates Analysis (PCoA), which is based on genetic distances, showed no anticipated clear grouping. Bayesian structure analysis revealed three genetic clusters. Analysis of FST (0.001-0.027) and Nei genetic distance (0.029-0.084) revealed that the genetic diversity of inter subpopulation in cattle groups was estimated to be lower than the genetic diversity of intra subpopulation.

Keywords: genetic variability, microsatellite, cattle

\section{INTRODUCTION}

Structured cattle development in Lithuania is observed since the beginning of the twentieth century (Skinkytè et al., 2005). Lithuanian Red, Lithuanian Red and White, Lithuanian Black and

* Corresponding author. Email: algimantas.paulauskas@vdu.lt
White are the main cattle breeds raised in Lithuania. To increase the phenotypic and genotypic parameters, they are bred with foreign species (Šveistienè, Jatkauskienè, 2008). The breed of the Lithuanian Black and White cattle was obtained by crossbreeding local cattle with Dutch Belted, German Black and White, and Swedish Black and White. It is important to mention that Lithuanian cattle are bred with Holstein cattle 
breed to increase the productivity (LBWCBA, 2011). The Lithuanian Red and Lithuanian Red and White cattle breeds were obtained by crossbreeding local cattle with Danish Red, Anglers, Swiss and Latvian Brown, Swedish Red and White, and sometimes with Simmentals. It is estimated that by increasing the percentage of the Lithuanian Red genotype in the individual, a negative effect on milk productivity is observed but it increases the lifetime of the individual (Japertiene et al., 2016). To increase the lifetime, crossbreeding with Anglers, Swedish Red and White, and Swiss Red is also suggested. To improve milk quality, crossbreeding with Ayrshire is advised, and to improve physical properties, Red and White Holstein, Danish Red are advised (Ministry of Agriculture of the Republic of Lithuania, 2003). The aim of the current study was to evaluate the genetic diversity among Lithuanian Black and White, Red and White, and Red cattle breeds in order to provide information for future breeding programmes.

\section{MATERIALS AND METHODS}

Lithuanian Black and White and Lithuanian Red Cattle Improvers' associations provided 192 ear tissue samples. DNA extraction was performed using Genomic DNA Purification Kit (Thermo Fisher Scientific, Lithuania) according to the manufacturer's recommendations and its concentration $(\mathrm{ng} / \mu \mathrm{l})$ was assessed using NanoDrop ${ }^{\text {Tw }} 2000$ (Thermo Fisher Scientific $\left.^{\mathrm{m} m}\right)$ spectrophotometer. DNA samples were stored at $-20^{\circ} \mathrm{C}$ until use. A set of 11 microsatellite loci (BTJAB1, BOVIRBP, BM6438, BM2830, BM1225, BM1818, TGLA122, ETH10, HEL9, CSSM66, TGLA227) used in this study were chosen from part of a panel markers recommended by the International Society of Animal Genetics (ISAG/FAO, 2004).

The final volume of the PCR mix was $15 \mu \mathrm{L}$, which contained $7.5 \mu \mathrm{L}$ of $2 \mathrm{X}$ PCR buffer, $2 \mu \mathrm{L}$ of the target DNA, $1 \mu \mathrm{L}$ of each primer pair, and $\mathrm{ddH}_{2} \mathrm{O}$, the volume of which was based on the missing final volume of the reaction mix. The forward primers for the screened polymor- phic loci were labelled with fluorescent dyes (5CY3 or 5-FAM) and their PCR products were separated by capillary electrophoresis using a SeqStudio Genetic Analyzer Sequencer (Applied Biosystems ${ }^{\oplus}$ ).

The allele size was determined using GeneMapper $^{\text {Tw }}$ 6.0 Software (Thermo Fisher Scientific, No. 4475073). The mean number of alleles per locus $(\mathrm{Na})$, expected heterozygosity $\left(\mathrm{H}_{\mathrm{E}}\right)$, and observed heterozygosity $\left(\mathrm{H}_{\mathrm{O}}\right)$ were calculated using GeneAlEx v. 6.5 (Peakall, Smouse, 2012). The Markov chain algorithm was used to calculate the exact $P$ value where the following parameters were used: 10,000 dememorization, 100 batches, and 1000 replications. Hierarchical molecular variance analysis (AMOVA) was performed using Arlequin v. 3.5.2.2 (Excoffier et al., 2010). The distribution of total genetic diversity between sample groups and individuals (excluding repetitive genotypes) was assessed using the FST (IAM) model. Groups of genetic clusters were identified by Bayesian cluster analysis according to the Markov chain algorithm (MCMC) for 200,000 iterations with 100,000 replications; each was run ten times with STRUCTURE 2.3.4 software (Pritchard et al., 2000). To summarise the obtained results, the CLUMPAK system package (Kopelman et al., 2015) analysis based on the formed Q - matrix was performed.

\section{RESULTS AND DISCUSSION}

A total of 88 different alleles were found in the group of Lithuanian Black and White (LBW) cattle breed, 98 in the Lithuanian Red (LR) cattle breed, and 106 in the Lithuanian Red and White (LRW) cattle breed. The observed heterozygosity $\left(\mathrm{H}_{\mathrm{O}}\right)$ and the expected heterozygosity $\left(\mathrm{H}_{\mathrm{E}}\right)$ ranged from 0.067 to 1.000 and from 0.065 to 0.887 , respectively. BM 2830 locus had the highest $\mathrm{H}_{\mathrm{E}}$ and $\mathrm{H}_{\mathrm{O}}$ in all three cattle breeds, except the CSSM66 locus, which had the highest expected heterozygosity rates in the LRW cattle breed. On the other hand, BOVIRBP had the lowest rates (0.067 and 0.065 , respectively) in LBW, LR, and LRW cattle breeds (Table 1). 


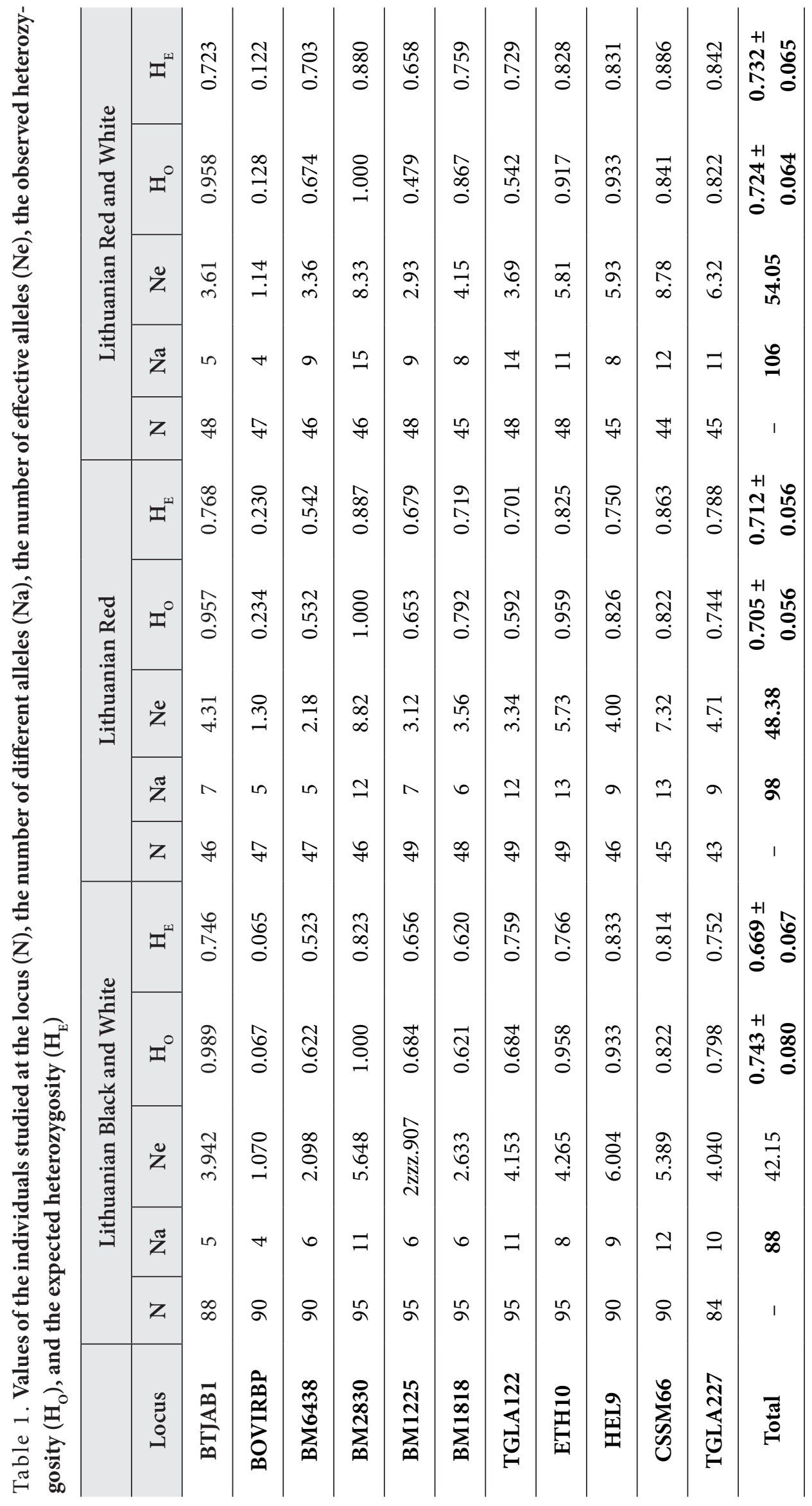


Thirty-two private alleles were detected in all cattle breeds (15 private alleles in LRW, nine private alleles in LBW, eight private alleles in LR). Private alleles were not detected in the HEL9 loci (Table 2). Private alleles usually appear in big populations due to random mutations, gene drift, or individuals' migration between populations. These alleles are specific and may have a crucial role in future breeding (Stolpovsky et al., 2020).

There is a clear tendency to form three groups of subpopulations based on allelic frequencies (Fig. 1). However, after executing Principal coordinates analysis (PCoA), which is based on genetic distances, no clear clustering was observed (Fig. 2).

Table 2. Distribution of private alleles in the populations of Lithuanian Black and White (LBW), Lithuanian Red (LR), and Lithuanian Red and White (LRW) cattle

\begin{tabular}{|c|c|c|c|c|}
\hline Locus & LBW & LR & LRW & $\begin{array}{c}\text { Number of } \\
\text { private alleles }\end{array}$ \\
\hline BTJAB1 & - & $216(0.011) ; 230(0.011)$ & - & 2 \\
\hline BOVIRBP & - & $141(0.011)$ & - & 1 \\
\hline BM6438 & - & - & $\begin{array}{c}262(0.011) ; 264(0.011) ; \\
280(0.011)\end{array}$ & 3 \\
\hline BM2830 & $165(0.005)$ & - & $\begin{array}{c}138(0.011) ; 140(0.011) \\
150(0.033)\end{array}$ & 4 \\
\hline BM1225 & $235(0.005)$ & - & $\begin{array}{c}231(0.010) ; 247(0.010) ; \\
259(0.021)\end{array}$ & 4 \\
\hline BM1818 & - & $270(0.010)$ & $240(0.011) ; 256(0.011)$ & 3 \\
\hline TGLA122 & $\begin{array}{c}164(0.015) ; 178 \\
(0.005) ; 182(0.005)\end{array}$ & $134(0.010)$ & $146(0.011) ; 168(0.010)$ & 6 \\
\hline ETH10 & $223(0.005)$ & $207(0.005) ; 211(0.042)$ & $220(0.010)$ & 4 \\
\hline CSSM66 & $\begin{array}{c}70(0.005) ; 104 \\
(0.027)\end{array}$ & $82(0.011)$ & - & 3 \\
\hline TGLA227 & $204(0.006)$ & - & $194(0.022)$ & 2 \\
\hline Total & 9 & 8 & 15 & 32 \\
\hline
\end{tabular}

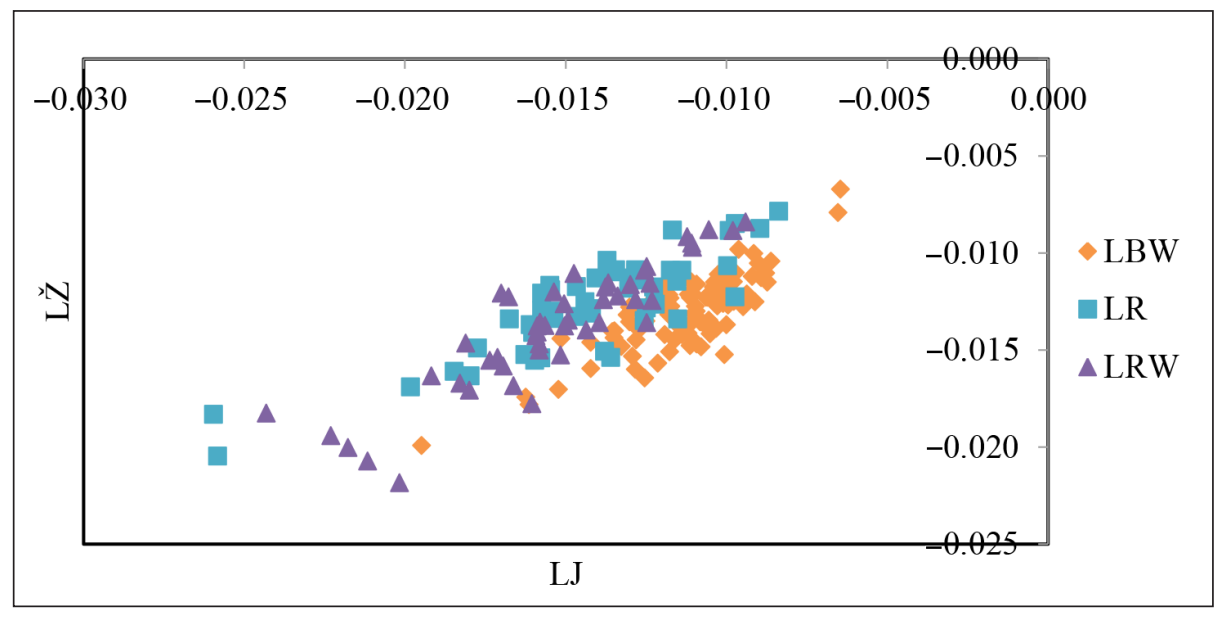

Fig. 1. Assignment of Lithuanian dairy cattle to subpopulations based on allele frequencies 


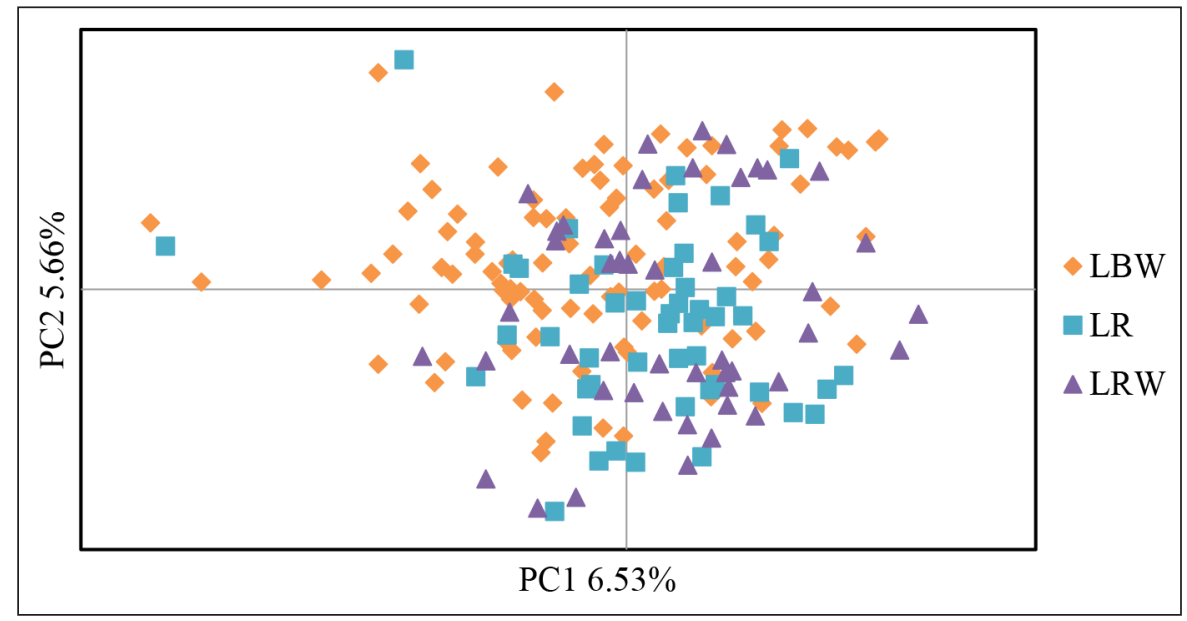

Fig. 2. Principal component analysis based on genetic distances of Lithuanian dairy cattle

Model-based clustering analysis revealed that Lithuanian dairy cattle had the highest $\Delta \mathrm{K}$ when $\mathrm{K}$ was set to 3; that provided an explanation for the genetic structure and levels of admixture for the populations. By completing CLUMPAK analysis, results were presented in the dispersed bar (Fig. 3).

To identify genetic differentiation between different cattle breeds, Nei genetic distances and FST values were obtained. Both parameters revealed low genetic differentiation between cattle breeds (the total mean value of FST was 0.019). Also, FST and Nei values were calculated for breed groups, where the highest value was observed between LBW and LRW $($ FST $=0.027$; Nei $=0.084)($ Table 3$)$.

Moreover, the analysis of molecular variance (AMOVA) was performed, which confirmed low genetic variability between subpopulations; however, it showed high genetic differentiation between individuals in subpopulations (Table 4).

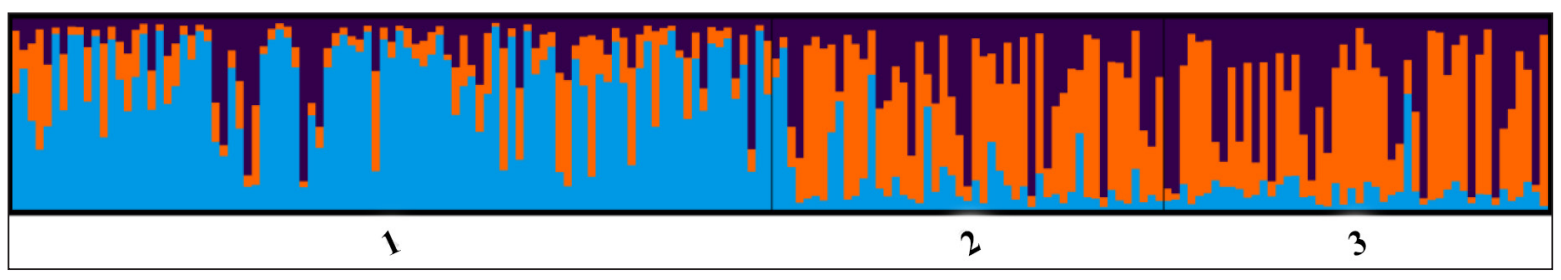

Fig. 3. Population structure of the three analysed cattle breeds obtained by using a model-based clustering method implemented in STRUCTURE for $\mathrm{K}=3$. Each column represents the proportion in which an individual belongs to a different-coloured cluster. 1 - Lithuanian Black and White; 2 - Lithuanian Red; 3 - Lithuanian White and Red

Table 3. Values of $\mathbf{F}_{S T}$ (below diagonal) and Nei (above diagonal) genetic distance between the subpopulations dairy cattle studied in Lithuania. Maximum values are highlighted

\begin{tabular}{c|c|c|c}
\hline LBW & LR & LRW & \\
\hline 0.000 & 0.071 & $\mathbf{0 . 0 8 4}$ & LBW \\
\hline 0.021 & 0.000 & 0.029 & LR \\
\hline $\mathbf{0 . 0 2 7}$ & 0.001 & 0.000 & LRW
\end{tabular}


Table 4. Values of degrees of freedom (d.f.), sum of squares (SS), and variance components expressed as a percentage of variability

\begin{tabular}{c|c|ccc|c}
\hline Source & d.f. & SS & Dispersion component & Variability \% \\
\hline Among populations & 1 & 14.152 & 0.06321 & $\mathbf{2 . 8 5}$ \\
\hline Within the population & 192 & 440.000 & 2.29167 & $\mathbf{9 7 . 1 5}$ \\
\hline Total & 193 & 480.152 & 2.35488 & 100
\end{tabular}

\section{DISCUSSION}

Investigation into genetic variability of Lithuanian cattle breeds using microsatellite primers is very important for the preservation and improvement of their phenotypic and genotypic properties. After studying 192 individuals, from $88(\mathrm{~N}=95)$ to $106(\mathrm{~N}=48)$ different alleles were found in subpopulations (292 being the total number of different alleles). The study conducted by Svishcheva et al. (2020) focused on cattle breeds in the Eurasian area, where it was found that the number of different alleles in the breeds of the European region ranged from $79(\mathrm{~N}=49)$ to $113(\mathrm{~N}=48)$. Ozsensoy and Kurar (2014) determined that an average of 13.45 different alleles are found per locus; in the study of Snegin et al. (2019), it ranged between 6.5 and 13.6 alleles per population, whereas in our study this value was 26.55 . These differences are due to the number of individuals in different populations (subpopulations), the values of the range of the markers used, and differences in breeds.

The $\mathrm{H}_{\mathrm{O}}$ values analysed in this study ranged from $0.705 \pm 0.056$ to $0.743 \pm 0.080$ and the $\mathrm{H}_{\mathrm{E}}$ values from $0.669 \pm 0.067$ to $0.732 \pm 0.065$. The values of the observed heterozygosity in the Swiss Brown breed (the breed used for Lithuanian Red crossbreeding) studied by Svishcheva et al. (2020) were 0.72 and 0.71 , which fully correlates with the data obtained in our study into the subpopulation of Lithuanian Black and White cattle (0.74 and 0.67).

During the analysis of private alleles, we found as many as 15 private alleles in our study into the subpopulation of the Lithuanian Red cattle breed $(\mathrm{N}=48)$. Van der Westhuizen et al. (2020) conducted a study with a larger popula- tion sample $(\mathrm{N}=550)$ and found 2-9 private alleles. Snegin et al. (2019) also found a lower number of private alleles (1-5 alleles per breed) in his study ( $\mathrm{N}=752)$. In our study, most of the private alleles (6) were found in the TGLA122 locus. In Snegin et al. (2019), the majority of private alleles were also found in the TGLA122 locus (4), and Svishcheva et al. (2020) found the largest number of private alleles in the TGLA227 locus (3) $(\mathrm{N}=1168)$, whereas in our study, two (one in LJ and one in LJM subpopulations) were found $(\mathrm{N}=192)$. A review of the overall trend and a comparison of the number of private alleles and the number of individuals tested suggest that the primers selected in this study were suitable for the identification of private alleles for the selected breeds.

The results of this study showed that the variation is $2.85 \%$ between subpopulations and 97.15\% within a population. Ozsensoy and Kurar (2014) examined native Turkish varieties and obtained a $2 \%$ variation between populations and $98 \%$ within a population. Meanwhile, Prusak et al. (2015) showed a $26.5 \%$ variation between populations and $73.5 \%$ within the population when studying local Polish cattle breeds.

The FST analysis among dairy cattle breeds (LBW, LR, LRW) resulted in overall FST $=0.019$. Among bovine subpopulations, the highest FST and Nei values $(F S T=0.027$; $\mathrm{Nei}=0.084$ ) were low compared to the results obtained from different studies. In a study conducted in Poland among the Black and White, Polish Black-Backed, and Polish Red populations, FST ranged from 0.247 to 0.941 (Prusak et al., 2015). According to Zatoń-Dobrowolska et al. (2007), FST values varied between 0.173 and 0.197 in Red cattle breeds; Nei values were 0.112-0.157. 
Meanwhile, Svishcheva et al. (2020) obtained the FST value of 0.153 value. In Snegin et al. (2019), the highest FST value among breeds was 0.469 and Nei 0.679 .

\section{CONCLUSIONS}

Our results provide new information about the genetic variability of the Lithuanian cattle breeds: Lithuanian Red, Lithuanian Red and White, Lithuanian Black and White. The results of the present study demonstrate low genetic variability between subpopulations; however, it showed high genetic differentiation between individuals within subpopulations. It is recommended to use these results for further Lithuanian cattle breeding to maintain high phenotypic and genotypic performance.

\section{ACKNOWLEDGEMENTS}

The authors are grateful for financial support from the National Paying Agency under the Ministry of Agriculture of the Republic of Lithuania via the Project of Genetic Analysis of Lithuanian Black and White, Holsteins, Lithuanian Red, and Lithuanian Red and White cattle breeds (grant No. MT-19-16). We would also like to thank Virgilijus Urbonavičius and Juozas Darbutas, the leaders of the Lithuanian Black and White and Lithuanian Red Cattle Improvers' Association, for providing tissue samples.

Received 17 July 2021

Accepted 18 August 2021

\section{References}

1. Excoffier L, Lischer HE. Arlequin suite ver 3.5: a new series of programs to perform population genetics analyses under Linux and Windows. Mol Ecol Resour. 2010; 10: 564-7.

2. ISAG/FAO. Secondary guidelines for development of national farm animal genetic resources management plans. Measurement of domestic animal diversity (MoDAD): Recommended microsatellite markers. 2004. p. 58. [Available from: http://www.fao.org/3/aq569e/aq569e.pdf].

3. Japertienè R, Anskienè L, Japertas S. Evaluation of the milk production and somatic cell count of Lithuanian purebred and crossbred dairy cows. Vet Med Zoot. 2016; 73: 51-7.

4. Kopelman NM, Mayzel J, Jakobsson M, Rosenberg NA, Mayrose I. Clumpak: a program for identifying clustering modes and packaging population structure inferences across $\mathrm{K}$. Mol Ecol Resour. 2015; 15: 1179-91.

5. Lithuanian Black and White cattle breeders' association (LBWCBA). Development of the Lithuanian Black and White cattle breed, people and their works at the turn of the century. 2011. p. 80. [Available from: https://zum.lrv.lt//uploads/zum/documents/files/LT_versija/Naujiena/Leidiniai/ Leidinys_\%E2\%80\%9ELietuvos_kaimo_ pletros_2007\%E2\%80\%932013m_programos_ igyvendinim_\%20apzvalga\%E2\%80\%9C/alvijuasocleidinukasENLT.pdf].

6. Ozsensoy Y, Kurar E. Genetic diversity of native Turkish cattle breeds: Mantel, AMOVA and bottleneck analysis. J Adv Vet Anim Res. 2014; 1: 86-93.

7. Peakall R, Smouse PE. GenAlEx 6.5: genetic analysis in Excel. Population genetic software for teaching and research-an update. Bioinformatics. 2012; 28: 2537-9.

8. Pritchard JK, Stephens M, Donnelly P. Inference of population structure using multilocus genotype data. Genetics. 2000; 155: 945-59.

9. Prusak B, Sawicka-Zugaj W, Korwin-Kossakowska A, Grzybowski T. Y chromosome genetic diversity and breed relationships in native polish cattle assessed by microsatellite markers. Turk J Biol. 2015; 39: 611-7.

10. Skinkytè R, Zwierzchowski L, Riaubaitè L, Baltrènaitè L, Miceikienè I. Distribution of allele frequencies important to milk production traits in Lithuanian Black \& White and Lithuanian Red cattle. Vet Med Zoot. 2005; 31: 93-7. 
11. Snegin EA, Kramarenko AS, Snegina EA, Kramarenko SS. Evaluation of genetic diversity and relationships among eight Russian and Ukrainian cattle breeds based on microsatellite markers. Regul Mech Biosyst. 2019; 10: 388-93.

12. Stolpovsky YA, Babayan OV, Kashtanov SN, Piskunov AK, Semina MT, Kholodova $M V$, et al. Genetic evaluation of the breeds of reindeer (Rangifer tarandus) and their wild ancestor using a new panel of STR markers. Russ J Genet. 2020; 56: 1469-83.

13. Šveistienè R, Jatkauskienè V. Analyses of the genetic diversity within Lithuanian WhiteBacked cattle. Vet Med Zoot. 2008; 44: 67-72.

14. Svishcheva G, Babayan O, Lkhasaranov B, Tsendsuren A, Abdurasulov A, Stolpovsky Y. Microsatellite diversity and phylogenetic relationships among East Eurasian Bos taurus breeds with an emphasis on rare and ancient local cattle. Animals, 2020; 10: 1493.

15. The Ministry of Agriculture of the Republic of Lithuania. Lithuanian domestic animal genetic resources - nowadays and future perspectives. 2003. p. 40. [Available from: http://www. fao.org/3/a1250e/annexes/CountryReports/ Lithuania.pdf].

16. van der Westhuizen L, MacNeil MD, Scholtz MM, Neser FW, Makgahlela ML, van Wyk JB. Genetic variability and relationships in nine South African cattle breeds using microsatellite markers. Trop Anim Health Prod. 2020; 52: 177-84.

17. Zatoń-Dobrowolska M, Čitek J, Filistowicz A, Řehout V, Szulc T. Genetic distance between the Polish Red, Czech Red and German Red cattle estimated based on selected loci of protein coding genes and DNA microsatellite sequences. Anim Sci Pap Rep. 2007; 25: 45-54.
Romualdas Lapickis, Loreta Griciuvienė, Asta Aleksandravičienė, Indrè Lipatova, Algimantas Paulauskas

\section{PIENINIŲ GALVIJŲ VEISLIŲ GENETINIS KINTAMUMAS LIETUVOJE}

\section{Santrauka}

Pagrindinis šio tyrimo tikslas - atlikti Lietuvos galvijų veislių genetinio kintamumo analizę. Tirtos trys veislès: Lietuvos juodmargiai (95), Lietuvos žalieji (49), Lietuvos žalmargiai (48). Genetiniam kintamumui ịvertinti buvo naudojama 11 fluorescencinių mikrosatelitinių žymenų. Visi lokusai pasižymèjo dideliu polimorfizmo laipsniu. Iš viso buvo aptikti 292 skirtingi aleliai (Na). Visose vertintose subpopuliacijose buvo aptikti 32 privatūs aleliai. Sugrupavus individus pagal alelių dažnius, nustatyta trijų atskirų grupių tendencija. Tačiau atlikus pagrindinių komponenčių analizę (PCoA), pagrịstą genetiniais atstumais, aiškaus grupavimosi, kurio buvo tikimasi, nenustatyta. Bajeso struktūros analizè atskleidè tris genetines grupes. Išanalizavus FST $(0,001-0,027)$ ir Nei genetinį atstumą $(0,029-0,084)$, mažesnè genetinè ịvairove nustatyta tarp subpopuliacijų nei subpopuliacijų viduje.

Raktažodžiai: genetinis kintamumas, mikrosatelitai, galvijai 